was obtained. Two years ago he liad a young man under his care, an undoubted case of aleoholic multiple neuritis, in which the symptoms were confined entirely to the lower extremities. In such a case it might have been diffieult for some observers to differentiate it from a beginning case of locomotor ataxia. The patient made a good recovery.

The sccond case of Dr. Camp's he thought had a suspicions history of exposure to leafl. although he had not been thus exposed for a good many years. One of the most marked eases of pseurlo-tabes that Dr. Lloyd had evcr seen, was reported from his Blockley clinic ten or twelve years ago. On making a eareful mieroscopic examination he found no trace of degenerative elianges in the eord. The man liad followed painting for many years, but also had a history of alcoliolism. This he thinks is the only matter of doubt about such cases, and raises a very interesting question. Anotluer interesting question, is the possibility of locomotor ataxia beginning as a multiple neuritis." He had seen cases which suggested this possibility. There is nothing inconceivable in it.

In closing Dr. Canp replied that in reference to the case in which there was a history of alcoholism bcing one of alcoholic neuritis, the patient had only been drinking for the last two or three years, and the symptoms dated baek nine years.

As regards the etiology in the second case where there was no history of syphilis nor alcoholism, there was only the one fact of the man having been a painter 20 years before. That is a long time to go back, but he supposed that if we have to theorize, there might be some connection between the two. Lead intoxication has been considered to be one of the causes of tabes.

As to Dr. Spiller's reference to a statement of Cole's, that he (Dr. Spiller) did not believe the posterior columns of the cord are degenerated in every case of multiple neuritis, Cole's exact words are, that he "could find no record of any case of multiple neuritis in wlich the spinal cord was examined by the Marchi method, in which it was stated that the posterior columns wcre iree from degeneration."

\title{
TRAUMA PRECEDING PROBABLE SYRINGOMYELIA AND TABES.
}

Dr. S. D. Ludlum presented these cascs:

Dr. Dercum thought one important point should be insisted on in these cases; that is, the relation of trauma should be clearly defined. He did not think too much stress should be laid on the fact of trauma in either of the cases presented by Dr. Ludlum. The relation of trauma to tabes has been gone over a great many times and none has cver been shown. He said that he understood that Dr. Ludlum disclaimed an etiological relationship with trauma in the cases presented.

Dr. Gordon said that the eases did not impress him as in any way cxtraordinary. Traumatic syringomyelia, as understood in its broadest sense. that is a hemorrliage or anything which involves in the spinal cord Gowers' tract, is a possibility. Dr. Gordon reealled that he presented before the Neurologieal Society a few years ago a woman who had a distinct history of trauma and developed distinct syringomyelie symptoms and atrophie disturbanees. As far as the tabes is eoncerned, he thought this a question of some importanee. At the last Congress of the French Netrologists and Alienists the question of traumatie paresis came up and observations were brought forward showing that the symptoms of paresis developed immediately after trauma. The general opinion nevertheless was that the tramma was simply an accidental cause. We know nothing of the previous eondition of the patient in regard to his knee jerks, his ocular symptoms, so it is difficult to draw even the slightest inferenee as to tramma as a factor in the causation of tabes.

Dr. Spiller said he did not believe trauma had been the cause in 
either of the cases presented, and Dr. Ludlum was of the same opinion. He did not believe that trauma is ever a cause of syringomyelia, unless the trauma directly affects the spinal column and spinal cord. Many writers have tried to show that trauma of the peripheral part of a limb, $i$. $e$, the hand, as in the boy presented, may be the cause of syringonyelia. He thought the case of the boy very interesting from the fact that his symptoms developed after the giving of a blow. $\mathrm{He}$ was not injured by the blow although immediately after giving it his hand commenced to swell and continued swollen for two years. The boy probably had syringomyelia before the trauma occurred. Hc presented the Brown-Séquard type of paralysis, $i$. $e$., he had disturbance of sensation in the left lower limb and of motion in his right upper and lower limbs.

Dr: A. R. Allen stated that the boy had given him, upon questioning, a history of excessive work for two years prior to this condition, carrying as much as a ton of coal a day in hods up to the third story of a building. Dr. Allen mentioned this point as possibly having something to do with his condition.

\section{A CASE OF ADIPOSIS DOLOROSA.}

By Dr. G. E. Price.

The patient was a femalc; white; widow; aged 54. She complained of severe pain about the knees, rarely spontancous, but induced by motion, palpation, or by contact of her flesh with any object. She had marked paresthesias (numbness, burning, tingling and crawling sensations), variously distributed. Her flesh would bruise without adequate cause and she manifested extreme fatigue upon slight exertion. The patient was nervous, irritable and anxious. Weight 225 lbs. Symptons developed $1 \mathrm{I} / 2$ years ago. Previous history: married when 25. Had never been pregnant, catarrhal jaundice when 37 , syphilis when 39 , sciatica. No history of alcoholism.

Family History-Father died of consumption. Rest negative.

Examination.-Nodular, lobulated masses of adipose tissue, very painftul when palpatcd, about knces, elbows and back of arms, face, hands and fcet unaffected, and trunk but slightly involved.

Thyroid gland not palpable. No muscular atrophy about hands, but had marked deformity of both little fingers and nodular deposits about many of the joints. Iarge varicose veins were present upon both legs. The skin was dry and the reflexes diminished.

The eyes were negative except for hyperemia of the discs. A few granular casts were found in the urine which was otherwise normal. The patient had shown distinct improvement following $5 / 2$ months' treatment with thyroid extract. Attention was called to the common history of antccedent syphilis or alcoholism in adiposis dolorosa.

Dr. Dercum thought the case a typical instance of adiposis dolorosa. The pathology of this disease is an interesting matter. Unfortunately it is one largely of speculation still, although in a number of cases at autopsy changes have been found in the thyroid gland, pituitary body and in the suprarenal capsules. There is probably some disturbance of the internal secretions. It is not inprobable that changes of the thyroid secretion leads the way, and that the disturbances of the other glands are probably secondary in character. However, whatever the original catse is, cases are benefited by the use of the thyroid extract, though Dr. Dercum thought it going too far to say they are cured. He has seen several cases greatly and persistently relieved.

Dr. D. J. McCarthy called attention to the fact that the case of adiposis dolorosa reported by Dr. Dercum and himself revealed later a very marked hypertrophy of the suprarenal capsules. He also alluded to an interesting case recently brought to post-mortem at the Philadelphia General Hospital. A German with multiple adipose tumors scattered mainly over the upper extremities, although there were a few over the lower, shortly before death had areas of painful swollen fat in the legs with what appeared to be forming tumors. This was of 